LOCAL WISDOM, 13 (1): 84 - 99, 2021
Local Wisdom Scientific Online Journal
ISSN: 2086-3764

\title{
Building Maintenance Assessment on Official Houses in Stilt Type at Jatiroto Sugar Factory Lumajang District, East Java, Indonesia
}

\author{
Wahyuni Eka Sari ${ }^{*}$, Antariksa ${ }^{2}$, Herry Santosa ${ }^{3}$ \\ $I^{*}$ Environmental Architecture Department, Faculty of Engineering, University of Brawijaya \\ ${ }^{2,3}$ Architecture Department, Faculty of Engineering, University of Brawijaya \\ Corresponding Author: sariekawahyuni@gmail.com
}

\begin{tabular}{|c|c|}
\hline & Abstract \\
\hline $\begin{array}{l}\text { Keywords: } \\
\text { Building Maintenance; } \\
\text { Cultural Significance; } \\
\text { Evaluative Descriptive; } \\
\text { Official Residence of the } \\
\text { Jatiroto Sugar Factory }\end{array}$ & $\begin{array}{l}\text { The complex of Jatiroto Sugar Factory did not only consist of factory } \\
\text { area, but also residential housing. The official house of Jatiroto Sugar } \\
\text { Factory was a house destined for the factory officials. On this area of } \\
\text { official house, a house was in stilt type. The stilt type in the complex } \\
\text { area of Jatiroto Sugar Factory was a unique type, it was differed from } \\
\text { the other types of official house. The official house in stilt type has a } \\
\text { fascinating specific feature to be examined. However, this official } \\
\text { house began to be neglected. A number of houses have been left and } \\
\text { not maintained because of the building oldness. The objective of this } \\
\text { research was to identify and assess the official house building at } \\
\text { Jatiroto Sugar Factory based on the cultural significance value of } \\
\text { building maintenance. The descriptive evaluative method was used to } \\
\text { assess the building of official house at Jatiroto Sugar Factory. The } \\
\text { descriptive method was done and aimed to identify the cultural } \\
\text { significance value of building maintenance, while the evaluative } \\
\text { method was aimed to determine the maintenance value, so it could } \\
\text { result to the value as a direction of building preservation. The result } \\
\text { was the value of cultural significance of building maintenance that } \\
\text { anld he wsed in the nreservation directives }\end{array}$ \\
\hline DOI: https:// doi.org & $\begin{array}{llll}0.26905 / \text { lw.v13i1.5108 } & \text { Article History } & \text { Received } & \text { : Dec 3, 2020 } \\
\text { blished by GKAK UNMER Malang } & \text { Accepted } & \text { : January 6, 2021 } \\
& & \text { Published } & \text { : January 15, 2021 }\end{array}$ \\
\hline
\end{tabular}

\section{INTRODUCTION}

Jatiroto Sugar Factory is a sugar factory in the district of Lumajang. The sugar factory of Jatiroto has been built during Dutch colonial government. The complex area of Jatiroto Sugar Factory has several parts, one of them is residential area of official house. This official house is functioned as the house for Dutch officials in the company.

Lumajang District has regarded Jatiroto Sugar Factory as the center of sugar miling activity. This Jatiroto Sugar Factory can fulfill the need of sugarcane milling into sugar from the region of Limajang District and its surroundings (Harnoko et al., 2018). The area of Jatiroto Sugar Factory is more than 100 years old, therefore the building in this area is now in a bad quality and condition. Moreover, it is because of lack of car and maintenance that turn some buildings in this area start to break and wreck. The Sugar Factory of Jatiroto is 
also the Indonesian government's asset that becomes a part of historical development of Indonesian sugar factory. The physical condition of building in the area of Jatiroto Sugar Factory in this current time affects the lack of visual quality of building and region.

The consideration of building preservation is a significant aspect for a building. The preservation is aimed to regard the meaning and value as the part of building, either from building's visual aspect or functional and sustainability aspect (Burra Charter, 1981). The building preservation on a cultural heritage can benefit for many parties. The benefit covers to the building itself, the building owner or developer, surrounding environment, and local government. The building of cultural heritage is an eyewitness of past story that nowadays can be delivered to the new generation about the preservation.

The building preservation is needed so the building or cultural heritage will not lose the cultural significance. The cultural significance is existed within a cultural heritage. It needs to a deep understanding to get the cultural significance in the form of process. Besides, the deep understanding is needed in order to avoid misinterpretation on the cultural significance. The study of this cultural significance is a quite important stage to do in order to plan the preservation directives, so the cultural significance within this cultural heritage building will remain well-preserved, and the real significance will not be misinterpreted.

Regarding to the façade of Dutch colonial building, it will show a specific style. The style will represent the past period during that old time. The style is a specific characteristic of particular time that can be identified the form until activity during that time. The past cultural activity can be a historical value for the building and area.

The style of Jatiroto Sugar Factory is identified from the visual aspect. The visual aspect can also affect to the spatial character of building. The Jatiroto Sugar Factory is more than 100 years old and the building starts to break. This condition which turns the buildings around Jatiroto Sugar Factory need a preservation. The special uniqueness of Jatiroto Sugar Factory is a fascinating aspect to be examined. The changes that occur over time make the building neglected and damaged. The building damage will cause the loss of architectural value of building.

The building preservation is very needed to preserve the building with its architectural values. Moreover, the cultural value and significance is contained within a building. According to the laws 10th, 2010 , the building is called as a cultural heritage when the building is more than 50 years old. The official house at Jatiroto Sugar Factory is already more than 50 years old, so it can decide the preservation directives for the building maintenance, and this building will be a cultural heritage building preserved by the local government.

Many of preliminary studies have discussed about the issue of preservation. There are several factors that can cause the damage on a building (Suprihatin et al., 2009). Many of problems appear due to the lack of adequate maintenance, so the building is neglected and left empty. The building neglect or lack of care will cause the damage of building. The building which has an attractive visual and spatial characteristics can be the decision factors of building preservation directives (Estin et al., 2017; Fajarwati et al., 2011; Handayani, 2011; Prameswari et al., 2017; Putra \& Ridjal, 2017; Sukarno et al., 2014). The building that has been preserved and maintained well will create a functional sustainability, either the old or new functions. Further, the preserved building will bring a positive value for the environment and surrounding area which regards the area as a historical and benefits for 


\section{Building Maintenance Assessment on Official Houses in Stilt Type at Jatiroto Sugar Factory Lumajang District, East Java, Indonesia \\ Wahyuni Eka Sari, Antariksa, Herry Santosa}

the local government and community (Azizu et al., 2011; Kurniawan, 2017; Permataasri et al., 2013)

The quality of building at Jatiroto Sugar Factory is now declined, thus the building is required to the preservation, especially on the part of official house. The official house in Jatiroto Sugar Factory has an aesthetical and cultural values, the values not only reflect the area of sugar factory, but also the visual image for Lumajang District. The visual characteristics in Dutch colonial nuance can be a fascinating point in this area. By doing this research, the researchers want to result the building assessment from the maintenance aspect that can be a directive of building's physical preservation. By this preservation, the building is expected to be well maintained and last for a long time. The building is now functioned as the official house of daily activities for the house owner. The preservation is aimed to prevent the building from the loss of significance and function, so it can support the activity of house owner.

\section{METHODS}

The research employed descriptive and evaluative methods. The descriptive method was aimed to describe and explain the physical condition of building based on field observation. The field observation was done directly in the location to seek the deficiency to be further identified and evaluate. The real condition of building was seen from the aspect of building maintenance. The evaluation employed evaluative method through numerical assessment. The number or score given on each assessment, 1 for the low category, 2 for the medium category, and 3 for the high category. The assessment was based on the cultural significance criteria. The significance values that have been determined were consisted of aesthetical value, historical value, utility value, architectural value, shape authenticity, and maintenance.

1. The aesthetical value would define the shape maintenance and layout of building

2. The historical value would affect to the building maintenance when it was related to the building age

3. The architectural was valued by the maintenance of building elements

4. The shape authenticity was related to the condition of building change

5 . The maintenance will be valued by the condition of building wholeness.

The values would affect to the decision of preservation directives. Moreover, the values would affect the changes that were allowed within the preservation attempt. The result of high value would determine the little changes on building, while the result of low value would enable the more changes. The more changes on building would decrease the possibility of authenticity loss.

This research took sample from the official house at Jatiroto Sugar Factory which was the stilt house type. The research location was precisely at Jatiroto Street, the house of $15^{\text {th }}$

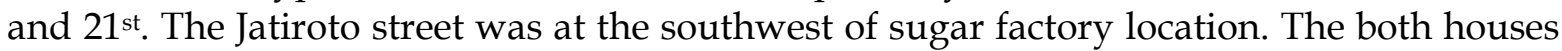
were facing north. The data was collected by visiting the houses directly in the field to be observed and identified, and then evaluated due to the cultural significance. 
LOCAL WISDOM, Vol. 13 No. 1 January 2021

Local Wisdom Scientific Online Journal

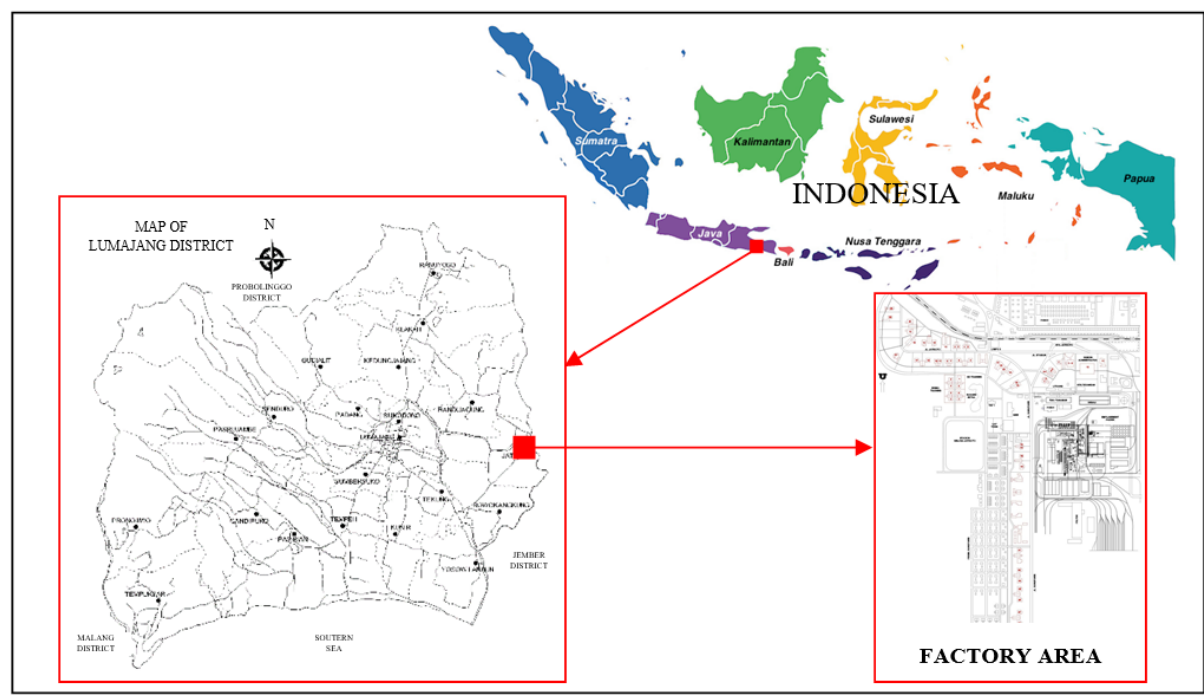

Location Study

Figure 1. Map of Lumajang District of Indonesia

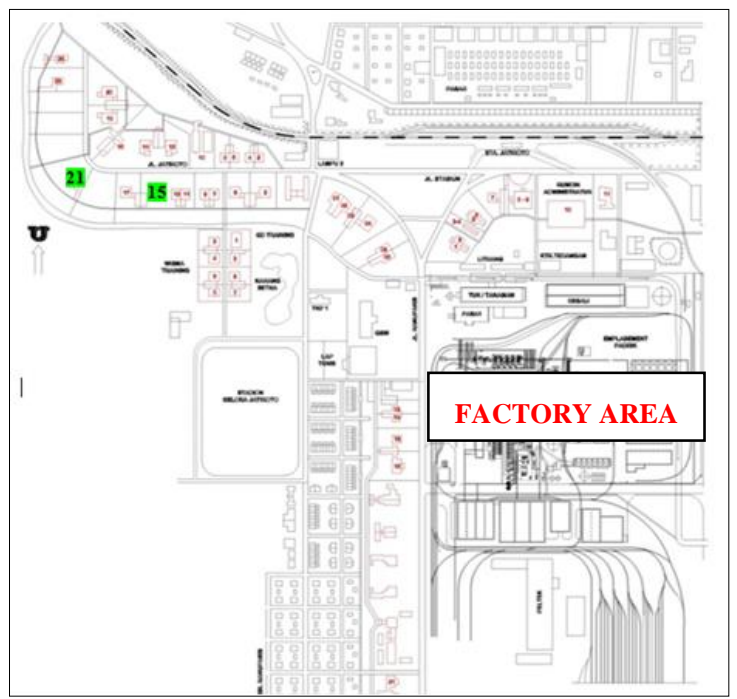

Figure 2. House Layout of Jatiroto Sugar Factory, Jatiroto Street Source: (Vembrista, 2017)

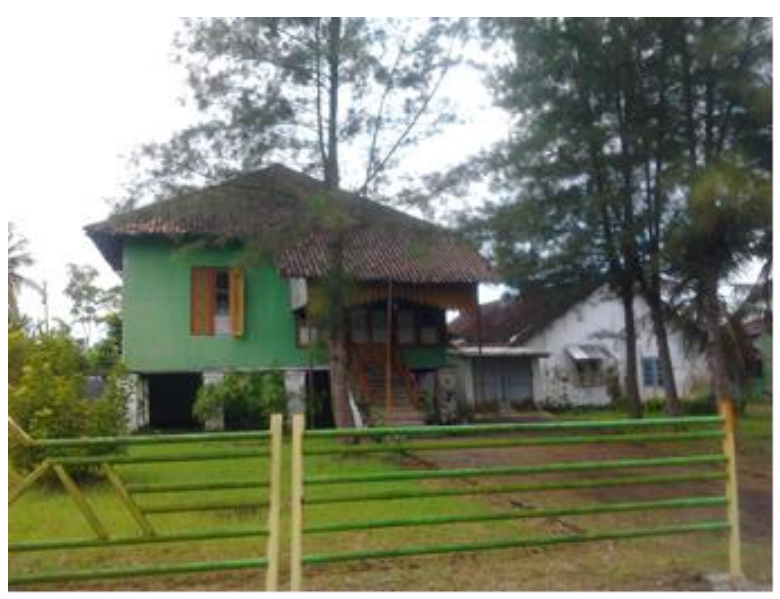

Figure 3. House at Jatiroto Street $15^{\text {th }}$ 


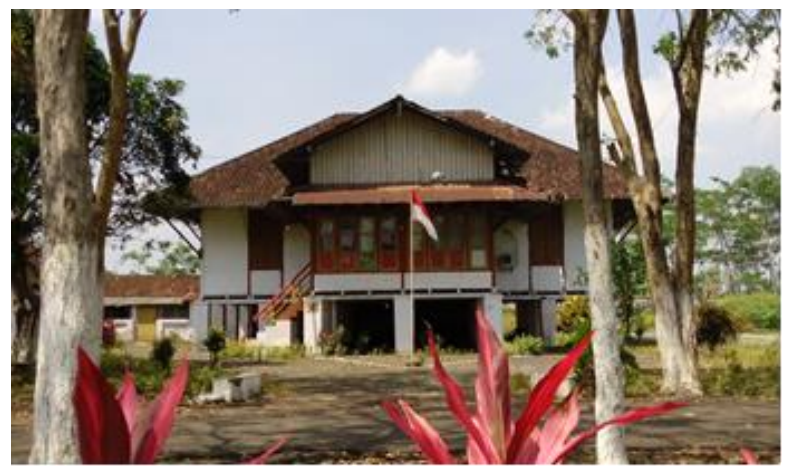

Figure 4. House at Jatiroto Street $21^{\text {st }}$

\section{LITERATURE REVIEW}

\section{Cultural Significance}

ICOMOS Charter for Places of Cultural Significance (ICOMOS (Australia), 2013) has explained that a preservation was an attempt to preserve the cultural significance or meaning from any cultural heritage, so it could continue the functional sustainability and benefit. Moreover, the initial step of preservation process before making the decision was to collect and analyze the information relating to cultural heritage value, which was covered to material, location, function, association, meaning, and note of the place. The result of analysis would deliver a statement and reason why the cultural object should be preserved.

The cultural significance was the step of preservation process (Purwaningsih, 2015). The place might have cultural meaning and values, but those things were invisible. The error of significance assessment could happen, since the meaning of place was invisible. Then, it needed to a study of cultural significance on the building of cultural heritage. The study of cultural significance was a way to understand the cultural values content. Next, the result would be the base of preservation strategy.

The Burra Charter (Burra Charter, 1981) has defined the values form cultural significance were aesthetical value, historical value, scientific value, social or spiritual value. The cultural significance was intangible, that could be seen from the material, layout, function, association, meaning, record or note, related places or objects. The material was referred to the forming material that could build a meaning on a space and regard an important element on a building. The layout was referred as the area around the building. The related places were the places that could contribute on cultural significance. The related objects were referred to the objects that could contribute to the cultural significance on other places outside the building.

The preservation attempt was done by using cultural significance and aimed to cover up the meaning inside the building (Martokusumo, 2017; Sutanto, 2014). This research was aimed to explain that a preservation without cultural significance value will be able to affect the condition of cultural heritage. Moreover, it was also aimed to observe the potential and function, from the historical value, building uniqueness, or area characteristic. This cultural heritage provided historical learning value that occurred in the past.

The building of cultural heritage which has characteristics and uniqueness worth to be preserved. The preserved building would reflect a beauty that was the heritage from legacy of time or specific style of certain period. The aesthetical and beauty value contained would be the cultural significance of place (Kerr, 1982). The assessment of cultural 
significance could be seen from the beauty aspect of building, like scale, shape, material, smell, structure, ornament, and sound. The building assessment was based on the building cultural significance as building façade of roof, wall, door, window, floor, column, and plafond. Bakri has explained further that the aesthetical value was based on color, shape, texture, smell and sound, also material. Further, the building function was also used in the assessment of cultural significance (Paramitha et al., 2017; Rahmadhiani, 2016; Suryono et al., 2013; Wahyuni, 2018).

The cultural significance could be a tool to assess the cultural significance (Feilden, 2003; Prabawa et al., 2019; Sutomo \& Surya, 2018). The next values used to be a measurement of cultural significance assessment were utility or functional value (Feilden, 2003; Prabawa et al., 2019; Suryono et al., 2013) and historical value. The other analysis which used to determine the preservation directive was the analysis on cultural significance due to the age, aesthetic, incredibility, historical role, scarcity, building character, and surrounding image (Catanese \& Snyder, 1979; Timang et al., 2016). The aesthetic value can be seen from the visual quality in the form of a building facade. The visual quality of building facades is very important in expressing the meaning and function of cultural heritage buildings (Piutanti, 2019). The maintained maintenance of the building will affect the visual quality of the building. Besides that, the visual quality of a facade will give an attractive impression and play an important role in the character of an area (Wijaya et al., 2019).

The cultural significance was based on aesthetical value, incredibility value, surrounding image, shape authenticity, maintenance, historical value, commercial value, and social value (Hastijanti, 2016). The aesthetical value was divided into sub-criteria of shape, structure, and ornament, the incredibility was seen from the effect of environmental landmark, surrounding landmark, and predominate building layout. The image of area was divided into area function, unity, and building contrast to the area. The shape authenticity was divided into the number of room in the building, structure element, construction, and ornament detail. The maintenance of building was also valued on damage level, percentage of building remainder, and cleanliness. The historical value was seen from the historical story of building architecture, historical story of city development, and historical story of nation. The commercial value was only based and seen from economic value. Meanwhile, the social and cultural value was based on the legend story that existed on the community also the cultural activity.

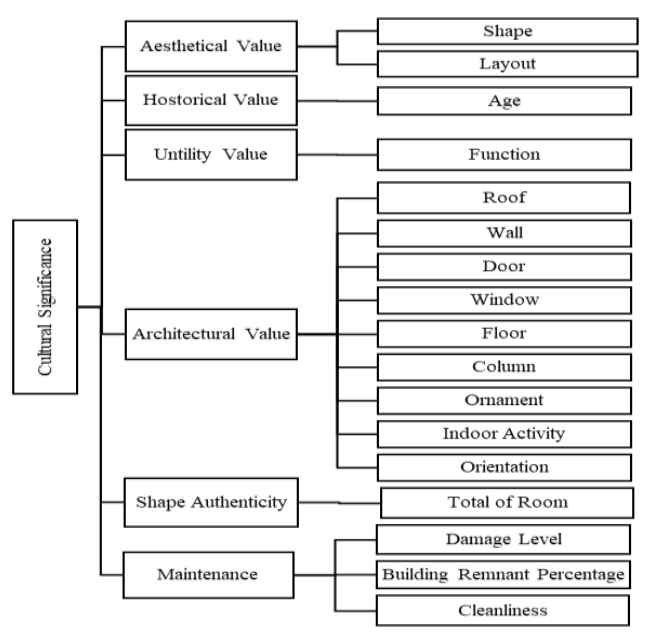

Figure 5. Elaboration of Cultural Significance Theory 


\section{Building Maintenance Assessment on Official Houses in Stilt Type at Jatiroto Sugar Factory Lumajang District, East Java, Indonesia \\ Wahyuni Eka Sari, Antariksa, Herry Santosa}

\section{RESULT AND DISCUSSION}

\section{Assessment on Building Maintenance}

The first house was a house at Jatiroto Street $15^{\text {th }}$. This house was the stilt house type. The building was oriented to north direction. The house building was dominated by square and rectangle shape. This statement was seen from the house blueprint. The roof view indicated the mix between square, rectangle shape also triangle shape. If a line was drawn on the blueprint, the blueprint referred to an asymmetrical balance. The changes were also found on the room pattern. The building changes occurred on the room function. The change of building function was on the service area in the right side of building that turned empty. The total space or room in this building were 13 rooms.

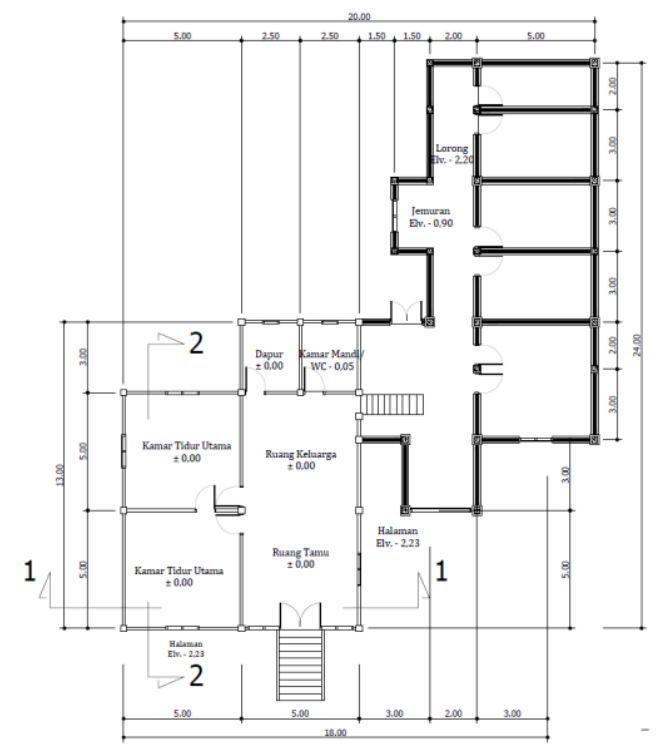

Figure 6. House Blueprint at Jatiroto Street $15^{\text {th }}$

The building roof was pyramid-shaped with material of clay tile. The additional roof was found in the front part as the front porch protector. The part of car garage space became the connector with the supporting area by using gable, while the supporting part used half-gable roof style. The ornament addition was in form of list plank in wood material and as the adaptation form to the local culture. The floor was made from wooden plank material. The building ornament on the front roof of building was gavel in wood material. The column used concrete structure with the dimension of $50 \mathrm{~cm} \times 50 \mathrm{~cm}$ on the main building. The gavel ornament was made from the rectangle wood material arranged in a row with the end of carvings.

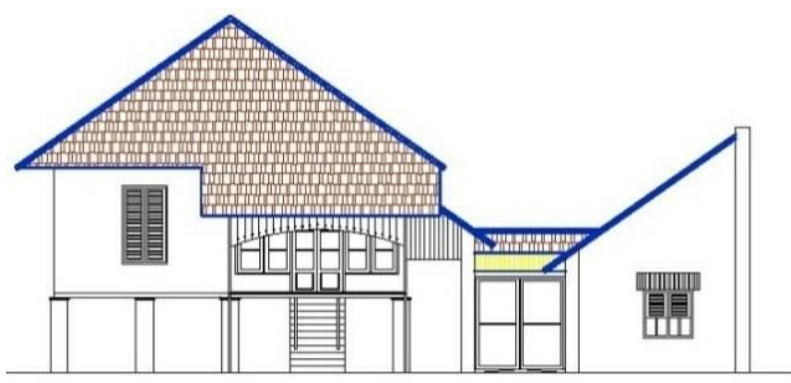

Figure 7. Front View at Jatiroto Street $15^{\text {th }}$ 


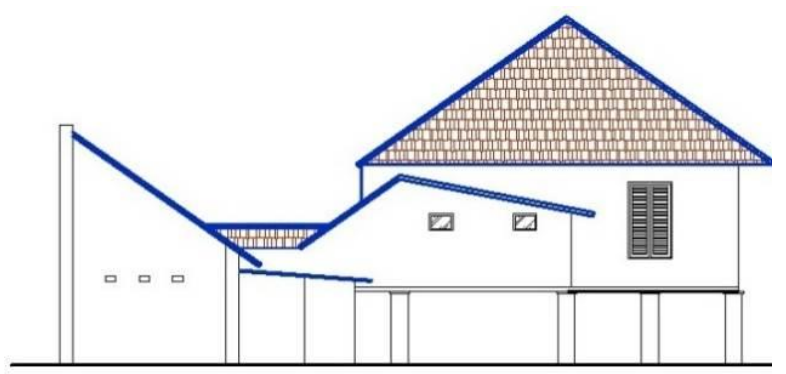

Figure 8. Back View at Jatiroto Street $15^{\text {th }}$

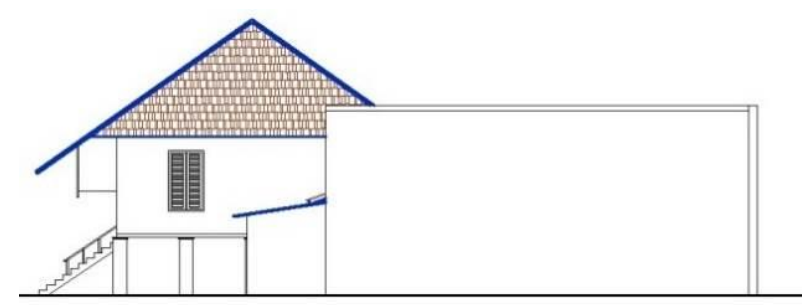

Figure 9. Left View at Jatiroto Street $15^{\text {th }}$

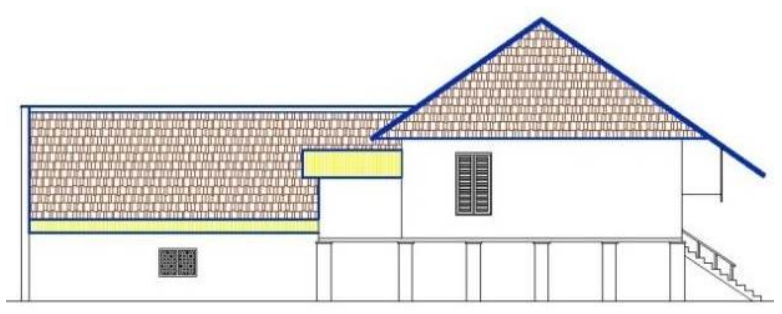

Figure 10. Right View at Jatiroto Street $15^{\text {th }}$

Table 1. Cultural Significance Assessment of Cultural Significance of House at Jatiroto Street $15^{\text {th }}$

\begin{tabular}{|c|c|c|c|c|c|c|c|c|c|c|}
\hline \multirow{2}{*}{ No. } & \multirow{2}{*}{$\begin{array}{l}\text { Variable of } \\
\text { Significance }\end{array}$} & \multirow{2}{*}{$\begin{array}{l}\text { Cultural } \\
\text { riteria }\end{array}$} & \multicolumn{6}{|c|}{ Score of Cultural Significance Criteria } & \multirow{2}{*}{ Value } & \multirow{2}{*}{ Assessment } \\
\hline & & & $\mathrm{E}$ & $S$ & G & A & B & $\mathrm{T}$ & & \\
\hline 1. & Shape & & 3 & 3 & 2 & 3 & 2 & 3 & 16 & High \\
\hline 2. & Layout & & 3 & 2 & 2 & 3 & 3 & 2 & 15 & Medium \\
\hline 3. & Age & & 3 & 2 & 2 & 3 & 3 & 2 & 15 & Medium \\
\hline 4. & Building Function & & 3 & 3 & 3 & 3 & 3 & 2 & 17 & High \\
\hline 5. & Room Function & & 3 & 3 & 3 & 3 & 3 & 2 & 17 & High \\
\hline 6. & Roof & & 2 & 3 & 3 & 3 & 3 & 2 & 16 & High \\
\hline 7. & Wall & & 3 & 2 & 3 & 3 & 3 & 2 & 16 & High \\
\hline 8. & Door & & 3 & 3 & 3 & 3 & 3 & 2 & 17 & High \\
\hline 9. & Window & & 3 & 3 & 3 & 3 & 3 & 2 & 17 & High \\
\hline 10. & Floor & & 3 & 2 & 3 & 3 & 3 & 3 & 17 & High \\
\hline 11. & Column & & 2 & 2 & 3 & 3 & 3 & 3 & 16 & High \\
\hline 12. & Ornament & & 3 & 2 & 3 & 3 & 3 & 2 & 16 & High \\
\hline 13. & Building Activity & & 2 & 2 & 2 & 2 & 2 & 2 & 12 & Medium \\
\hline 14. & Room Orientation & & 3 & 2 & 2 & 2 & 2 & 2 & 13 & Medium \\
\hline 15. & Total of Room & & 3 & 2 & 2 & 2 & 3 & 2 & 14 & Medium \\
\hline 16. & Damage Level & & 2 & 2 & 3 & 2 & 2 & 2 & 13 & Medium \\
\hline 17. & $\begin{array}{r}\text { Percentage of } \\
\text { Remnants }\end{array}$ & Building & 3 & 3 & 2 & 2 & 2 & 2 & 14 & Medium \\
\hline 18. & Cleanliness & & 2 & 2 & 2 & 2 & 2 & 2 & 12 & Medium \\
\hline & & & & & & & & Total & 273 & \\
\hline & & & & & & & & Mean & 15,2 & Medium \\
\hline
\end{tabular}




\section{Building Maintenance Assessment on Official Houses in Stilt Type at Jatiroto Sugar Factory Lumajang District, East Java, Indonesia \\ Wahyuni Eka Sari, Antariksa, Herry Santosa}

The mean value of cultural significance on house at Jatiroto Street $15^{\text {th }}$ was 15,2 , thus, then it resulted the medium potential assessment of preservation decision. The damage level on this house was categorized in low damage level, which only the side part was left empty. The building was still in whole shape with the percentage of building $100 \%$ and a little minor damage. The building cleanliness was maintained on the occupied part of building. The back part of building was left empty, so it turned dirty because it was used as the warehouse. The building maintenance value was mediate. This statement was based on the building condition that was not fully well-maintained, even the building was utilized. Some parts of building were not functioned, so it created the image of slum house at the bottom part of stilt house. The main building part used for the activity was still in a good condition. The part other than the stilt house was used as the car garage. The wall element of building was still in a good condition, but dirty and mossy. The roof element of building was also in a good condition, and the door and window were still in a good condition.

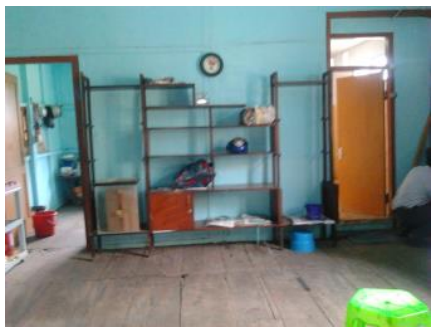

Figure 11. Building Maintenance Condition Inside of House at Jatiroto Street $15^{\text {th }}$

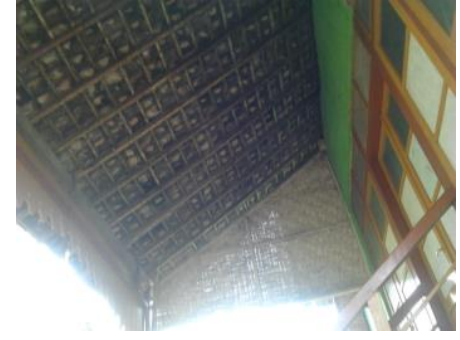

Figure 12. Building Maintenance Condition of Ceiling of House at Jatiroto Street $15^{\text {th }}$

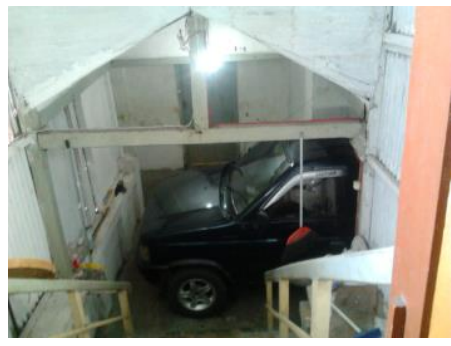

Figure 13. Building Maintenance Condition of Right Side of House at Jatiroto Street $15^{\text {th }}$

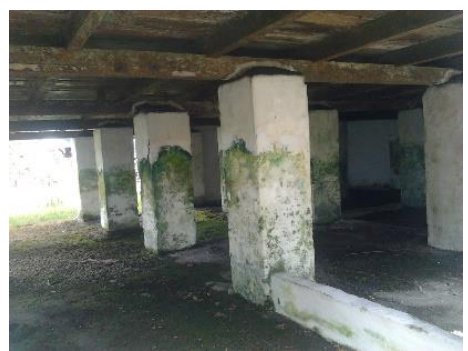

Figure 14. Building Maintenance Condition Underneath of House at Jatiroto Street $15^{\text {th }}$ 


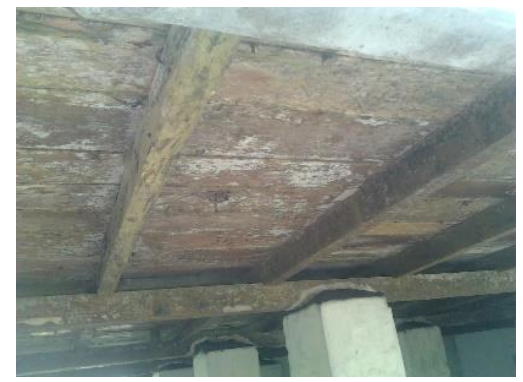

Figure 15. Building Maintenance Condition the Bottom of the Wooden Floor of House at Jatiroto Street $15^{\text {th }}$

The second house was a house at Jatiroto Street $21^{\text {st. }}$. The second house has northeast orientation. It was the stilt house type. Based on the blueprint, the shape was dominated by the square and rectangle shape. If it was drawn a vertical or horizontal line on the blueprint, it has an asymmetrical balance. Based on the view, the house has a combination of square and triangle shape. The balance resulted from the view was the asymmetrical balance. The total of space in the second house were 14 rooms. On the second house, it was not found a change on spatial function.

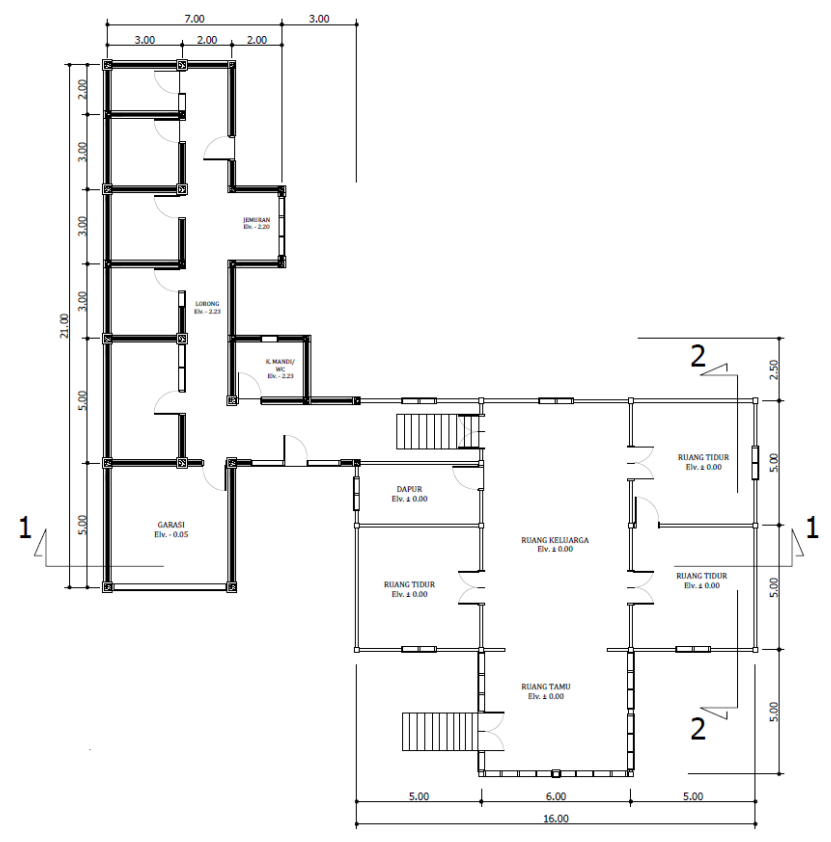

Figure 16. House Blueprint at Jatiroto Street $21^{\text {th }}$

The roof element of building used gable model with clay tile material. The other materials were zinc waves on the front part as canopy or roof cover. The canopy was functioned to protect the area of living room from the sunlight and raindrops. The area of living room used gable roof which became one with the roof shield on the back that resulted to a combination shape of roof. The wall element of building used wood and glass material. Next, the floor material was wooden board on the main building, while plaster floor on the side building. The second house was the stilt house which has the structure 
Building Maintenance Assessment on Official Houses in Stilt Type at Jatiroto Sugar Factory Lumajang District, East Java, Indonesia

Wahyuni Eka Sari, Antariksa, Herry Santosa

column with dimension of $50 \mathrm{~cm} \times 50 \mathrm{~cm}$. The column on the lower part of main building. The ornament of building was on gavel which functioned as air ventilation with wood material in a row.

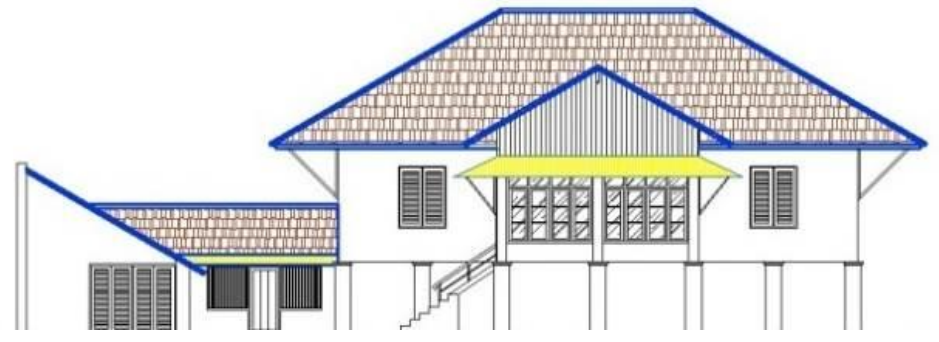

Figure 17. Front View of House at Jatiroto Street $21^{\text {st }}$

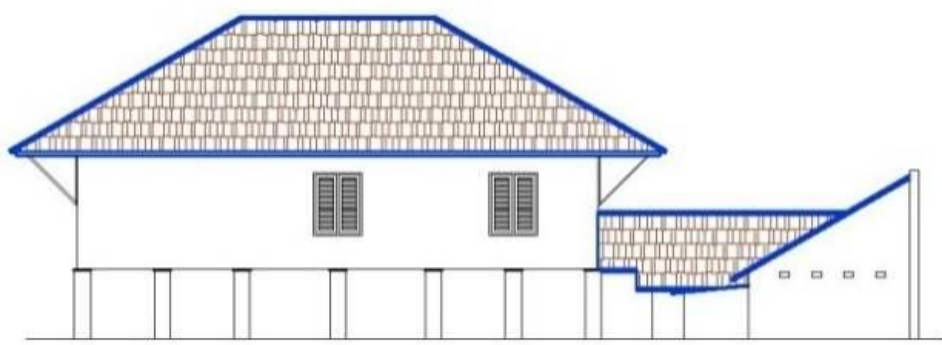

Figure 18. Back View of House at Jatiroto Street $21^{\text {st }}$

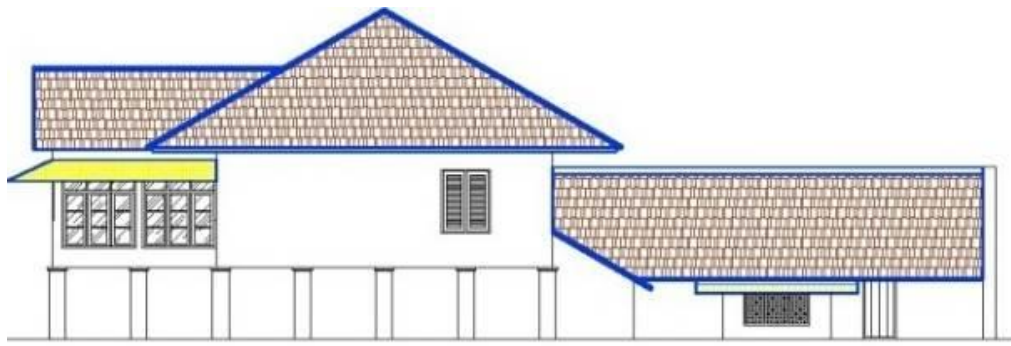

Figure 19. Left View of House at Jatiroto Street $21^{\text {st }}$

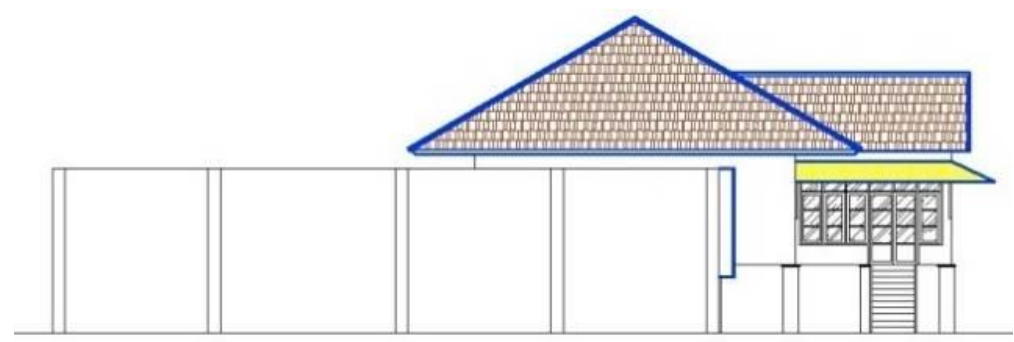

Figure 20. Right View of House at Jatiroto Street $21^{\text {st }}$ 
LOCAL WISDOM, Vol. 13 No. 1 January 2021

Local Wisdom Scientific Online Journal

Tabel 2. Cultural Significance Assessment of House at Jatiroto Street $21^{\text {st }}$

\begin{tabular}{|c|c|c|c|c|c|c|c|c|c|c|}
\hline \multirow{2}{*}{ No. } & \multirow{2}{*}{$\begin{array}{l}\text { Variable } \\
\text { Sigr }\end{array}$} & \multirow{2}{*}{$\begin{array}{l}\text { Cultural } \\
\text { riteria }\end{array}$} & \multicolumn{6}{|c|}{ Score of Cultural Significance Criteria } & \multirow{2}{*}{ Value } & \multirow{2}{*}{ Assessment } \\
\hline & & & $\mathrm{E}$ & S & G & A & B & $\mathrm{T}$ & & \\
\hline 1. & \multicolumn{2}{|l|}{ Shape } & 3 & 3 & 2 & 2 & 3 & 2 & 15 & Medium \\
\hline 2. & \multicolumn{2}{|l|}{ Layout } & 2 & 2 & 3 & 2 & 3 & 3 & 15 & Medium \\
\hline 3. & \multicolumn{2}{|l|}{ Age } & 3 & 3 & 3 & 2 & 3 & 2 & 16 & High \\
\hline 4. & \multicolumn{2}{|l|}{ Building Function } & 3 & 2 & 3 & 2 & 3 & 3 & 16 & High \\
\hline 5. & \multicolumn{2}{|l|}{ Room Function } & 3 & 2 & 3 & 2 & 3 & 3 & 16 & High \\
\hline 6. & \multicolumn{2}{|l|}{ Roof } & 3 & 2 & 3 & 3 & 3 & 2 & 16 & High \\
\hline 7. & \multicolumn{2}{|l|}{ Wall } & 3 & 2 & 3 & 3 & 3 & 2 & 16 & High \\
\hline 8. & \multicolumn{2}{|l|}{ Door } & 3 & 2 & 3 & 3 & 3 & 2 & 16 & High \\
\hline 9. & \multicolumn{2}{|l|}{ Window } & 3 & 2 & 3 & 3 & 3 & 2 & 16 & High \\
\hline 10. & \multicolumn{2}{|l|}{ Floor } & 3 & 2 & 3 & 3 & 3 & 2 & 16 & High \\
\hline 11. & \multicolumn{2}{|l|}{ Column } & 3 & 2 & 3 & 3 & 3 & 2 & 16 & High \\
\hline 12. & \multicolumn{2}{|l|}{ Ornament } & 2 & 2 & 2 & 2 & 2 & 2 & 12 & Medium \\
\hline 13. & \multicolumn{2}{|l|}{ Building Activity } & 2 & 2 & 2 & 2 & 2 & 2 & 12 & Medium \\
\hline 14. & \multicolumn{2}{|l|}{ Room Orientation } & 3 & 2 & 2 & 3 & 3 & 2 & 15 & Medium \\
\hline 15. & \multicolumn{2}{|l|}{ Total of Room } & 3 & 2 & 3 & 3 & 3 & 2 & 16 & High \\
\hline 16. & \multicolumn{2}{|l|}{ Damage Level } & 2 & 2 & 3 & 2 & 2 & 2 & 13 & Medium \\
\hline 17. & \multicolumn{2}{|l|}{$\begin{array}{c}\text { Percentage of } \\
\text { Remnants }\end{array}$} & 2 & 2 & 3 & 2 & 2 & 2 & 13 & Medium \\
\hline \multirow[t]{3}{*}{18.} & \multicolumn{2}{|l|}{ Cleanliness } & 2 & 2 & 3 & 2 & 2 & 2 & 13 & Medium \\
\hline & & & & & & & & Total & 268 & \\
\hline & & & & & & & & Mean & 14,9 & Medium \\
\hline
\end{tabular}

The mean value of cultural significance on the house at Jatiroto Street $21^{\text {st }}$ was 14,9 , thus it resulted the medium potential assessment of preservation decision. The damage level on second house was a minor damage which the only back part was left empty and dormant. The percentage of building remnant was still $98 \%$ with a minor damage. The building cleanliness was good in the area of occupied building. The back and side building which left empty looked more dirty. The weeds were around the house. The condition of building elements like wall, roof, door, and window were still in a good condition. The building deficiency was only at the building cleanliness that was not always maintained properly.

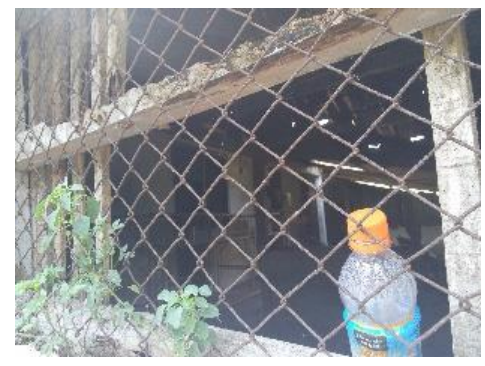

Figure 21. Building Maintenance Condition Inside of House at Jatiroto Street $21^{\text {st }}$

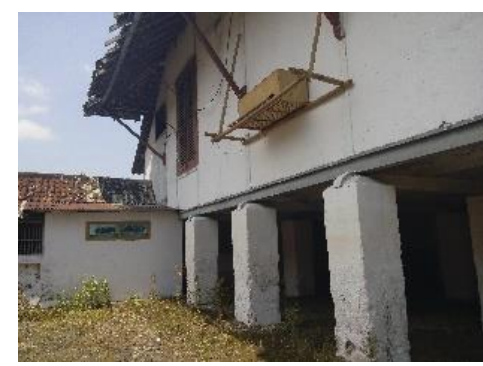

Figure 22. Building Maintenance Condition Right Side of House at Jatiroto Street $21^{\text {st }}$ 


\section{Building Maintenance Assessment on Official Houses in Stilt Type at Jatiroto Sugar Factory Lumajang District, East Java, Indonesia \\ Wahyuni Eka Sari, Antariksa, Herry Santosa}

Figure 22. Building Maintenance Condition Right Side of House at Jatiroto Street $21^{\text {st }}$

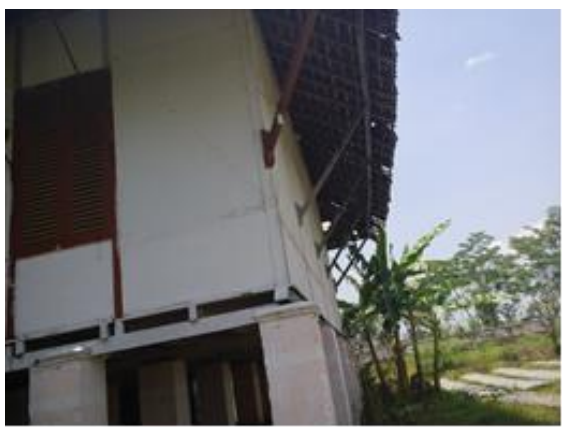

Figure 23. Building Maintenance Condition of Wall and Ceiling of House at Jatiroto Street $21^{\text {st }}$

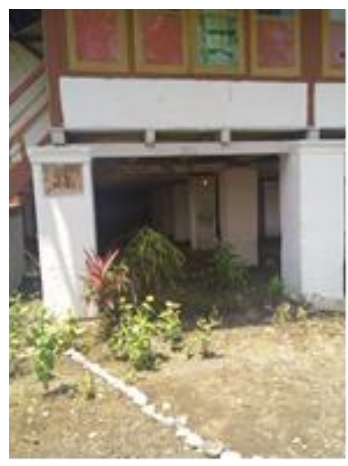

Figure 24. Building Maintenance Condition Underneath of House at Jatiroto Street $21^{\text {st }}$

\section{CONCLUSSIONS}

This research finally concluded that the assessment of cultural significance on the building maintenance value could be used in the attempt of government to plan building preservation directives. Generally, the official house building in stilt type at Jatiroto Sugar Factor acquired medium value during the assessment of building maintenance. The building maintenance could be identified from the building conditions as building remnants percentage, building cleanliness, and building damage level. Each building has different maintenance level, therefore it resulted the different value. However, the assessment was mostly categorized into a medium potential assessment of preservation decision. The preservation directive which could be employed was seed from the directions of building's physical condition. The building maintenance could be done periodically. It needed to the cleaning and repainting on the wall, roof, door, window, floor, and column parts. The repainting wad one by choosing the color fit to the initial and authentic color of building. During the painting process, it needed to be coated by anti-fungal material in order to keep the color resistance and avoid from moss. The rooms or spaces that left empty could be occupied by giving a new function of room. Moreover, the bathroom could be utilized. It was important to maintain the building cleanliness by cleaning the empty rooms periodically. 


\section{REFERENCES}

Azizu, N. N., Antariksa, \& Wardhani, D. K. (2011). Pelestarian Kawasan Benteng Keraton Buton (Preservation of the Buton Palace Fortress Area). Arsitektur E-Journal, 4(1), 1528.

Burra Charter. (1981).

Catanese, A. J., \& Snyder, J. C. (1979). Introduction to Urban Planning. McGraw-Hill.

Estin, N., Antariksa, \& Suryasari, N. (2017). Pelestarian Bangunan Kolonial Belanda Di Jalan Pemuda Depok (Preservation of Dutch Colonial Buildings on Pemuda Street Depok). Jurnal Mahasiswa Jurusan Arsitektur Universitas Brawijaya, 9(2), 52-59.

Fajarwati, A. N., Antariksa, \& Suryasari, N. (2011). Pelestarian Bangunan Utama Eks Rumah Dinas Residen Kediri (Preservation of the Main Building of the Former Kediri Resident Service House). Arsitektur E-Journal, 4(2), 85-105.

Feilden, B. (2003). Conservation of Historic Buildings (New editio). Routledge. https://doi.org/10.4324/9780080502915

Handayani, T. (2011). Identifikasi Karakteristik Facade Bangunan Untuk Pelestarian Kawasan Pusaka di Ketandan, Yogyakarta (Identification of Building Facade Characteristics for Conservation of Heritage Areas in Ketandan, Yogyakarta). Jurnal Arsitektur, 9(1), 55-68.

Harnoko, D., Nurdiyanto, \& Nurhajarini, D. R. (2018). Pabrik Gula Djatiroto (Djatiroto Sugar Factory) (2018th ed.). Budaya (BPNB). https://perpuslpmpjabar.kemdikbud.go.id/index.php?p=show_detail\&id=4853\&keywords=

Hastijanti, R. (2016). Analisis Penilaian Bangunan Cagar Budaya (Analysis of Cultural Heritage Building Assessment). Research Gate, October, 1-8. https://doi.org/10.13140/RG.2.2.13923.96805

ICOMOS (Australia). (2013). Burra Charter: The Australia ICOMOS Charter for Places of Cultural Significance (1999). Encyclopedia of Global Archaeology, 1078-1082. https://doi.org/10.1007/978-1-4419-0465-2_1046

Kerr, J. S. (1982). The Conservation Plan: A Guide to the Preparation of Conservation Plans for European Cultural Significant (1st Editio). National Trust of Australia (NSW).

Kurniawan, A. (2017). Identifikasi bangunan kolonial untuk pelestarian fasade di jalur belanda kota singaraja bali (Identification of colonial buildings for the preservation of facades on the Dutch route, Singaraja, Bali). SAMARTA, 17-24.

Martokusumo, W. (2017). Pemaknaan Tempat dalam Pelestarian Arsitektur (Meaning of Place in Architectural Preservation). Seminar Heritage Ikatan Peneliti Lingkungan Binaan Indonesia (IPLBI), 001-010. https://doi.org/10.32315/sem.1.001

Paramitha, I. A. D., Kastawan, I. W., \& Widiastuti. (2017). Nilai Signifikansi Cagar Budaya Hotel Inna Bali Jalan Veteran Denpasar (The Cultural Heritage Significance Value of Hotel Inna Bali Veteran Street Denpasar). SPACE, 4(3), 113-128. 


\section{Building Maintenance Assessment on Official Houses in Stilt Type at Jatiroto Sugar Factory Lumajang District, East Java, Indonesia \\ Wahyuni Eka Sari, Antariksa, Herry Santosa}

https://doi.org/https://doi.org/10.24843/JRS.2017.v04.i02.p02

Permataasri, W. G., Antariksa, \& Siregar, J. P. (2013). Pelestarian Kawasan Pabrik Gula Watoe Toelis Sidoarjo (Preservation of Sugar Factory Area Watoe Toelis Sidoarjo). Arsitektur E-Journal, 6(2), 115-129.

Piutanti, R. (2019). Typology of fasade building in kayu tangan street corridor, Malang City. Local Wisdom: Jurnal Ilmiah Kajian Kearifan Lokal, 11(2), 107-120. https:// doi.org/10.26905/lw.v11i2.2858

Prabawa, M. A. A., Adhika, I. M., \& Wirawibawa, I. B. G. (2019). Konservasi Arsitektur Pura Berbasis Komunitas Di Pura Dasar Buana Gelgel, Klungkung (Conservation of Community-Based Temple Architecture at Pura Dasar Buana Gelgel, Klungkung). SPACE, 6(1), 5-20. https://doi.org/https://doi.org/10.24843/JRS.2019.v06.i01.p02

Prameswari, T. A., Suryasari, N., \& Antariksa. (2017). Pelestarian Bangunan Kolonial Belanda Kantor Gubernur Jawa Timur ( Gouverneur Kantoor Van Oost Java ) (Preservation of Dutch Colonial Buildings, East Java Governor's Office (Gouverneur Kantoor Van Oost Java)). Jurnal Mahasiswa Arsitektur UB, 1-9.

Purwaningsih, L. H. (2015). Kajian Signifikansi Budaya ( Cultural Significance ) Pada Permukiman Pecinan Tangerang (Cultural Significance Study (Cultural Significance) in the Chinatown in Tangerang). Local Wisdom and Cultural Sustainability, 79-88.

Putra, B. N., \& Ridjal, A. M. (2017). Pelestarian Bangunan Kolonial Museum Fatahillah Di Kawasan Kota Tua Jakarta (Preservation of the Colonial Building of the Fatahillah Museum in the Old City Area of Jakarta). Jurnal Mahasiswa Jurusan Arsitektur Universitas Brawijaya, $5(1)$. http://arsitektur.studentjournal.ub.ac.id/index.php/jma/article/view/338

Rahmadhiani, Y. (2016). Analisis Karakter Visual Arsitektural Dan Penilaian Makna Kultural Sebagai Pendekatan Pelestarian Bangunan Kolonial Inna Bali Hotel Di Denpasar (Analysis of Visual-Architectural Characteristics and Assessment of Cultural Meanings as Approaches to the Preservation of Colonial Buildings in Inna Bali Hotel in Denpasar). SPACE, 3(1), 53-66. https:/ / doi.org/10.24843/JRS.2016.v03.i01.p05

Sukarno, P. G., Antariksa, \& Suryasari, N. (2014). Pelestarian Bangunan Kolonial Belanda Rumah Dinas Bakorwil Kota Madiun (Preservation of Dutch Colonial Buildings Madiun City Bakorwil Officuial House). Arsitektur E-Journal, 7(1), 39-51.

Suprihatin, A., Antariksa, \& Meidiana, C. (2009). PELESTARIAN LINGKUNGAN DAN BANGUNAN KUNO DI KAWASAN PEKOJAN JAKARTA (Preservation Of the Area And Old Buildings In The Pekojan Area Of Jakarta). Jurnal Tata Kota Dan Daerah, $1(1), 1-12$.

Suryono, A., Sudikno, A., \& Salura, P. (2013). Conservation of Dutch Colonial Architecture Heritage On Rectorate Building of Education University of Indonesia in Bandung. J. Basic. Appl. Sci. Res, 3(8), 418-422. https://www.researchgate.net/publication/280546420_Conservation_of_Dutch_Colo 
nial_Architecture_Heritage_on_Rectorate_Building_of_Education_University_of_Ind onesia_bandung/link/55b888f608ae9289a08d62cd/download

Sutanto, A. (2014). Faktor-faktor Keterbengkalaian Benteng Toboali sebagai Bangunan Bersejarah (Abandonment of Toboali Fort as a Historical Building). Jurnal Pembangunan Wilayah \& Kota, 10(1), 94-105. https:/ / doi.org/10.14710/pwk.v10i1.7636

Sutomo, I. T., \& Surya, A. (2018). Cultural Significance: Kawasan Bersejarah Kota Siak Sri Indrapura (Cultural Significance: The Historical Area of Siak Sri Indrapura City). Seminar Kota Layak Huni/Livable Space, 213-212. https://www.trijurnal.lemlit.trisakti.ac.id/lslivas/article/view/2763/2389

Timang, V. V. S., Antariksa, A., \& Ari, I. R. D. (2016). Pelestarian Dukun Buntula'bi Balusu sebagai Warisan Budaya Di Kabupaten Toraja Utara (Preservation of Dukun Buntula'bi Balusu as a Cultural Heritage in North Toraja Regency). Jurnal Penataan Ruang, 11(1), 10-22. https:/ / doi.org/10.12962/j2716179X.v11i1.5214

Vembrista, G. (2017). Karakter Spasial dan Karakter Visual Rumah Dinas Kolonial Belanda Pabrik Gula Jatiroto (Spatial Characters and Visual Characters of the Dutch Colonial Service House Jatiroto Sugar Factory). Universitas Brawijaya.

Wahyuni, S. (2018). Placemaking Sebagai Strategi Revitalisasi Kawasan Studi Kasus: Kawasan Pecinan Kota Makassar (Placemaking as a strategy to revitalize the area. Case Study: Makassar Chinatown). Jurnal Linears, 1(2), 103-111. https://doi.org/10.26618/j-linears.v1i2.1815

Wijaya, B. T., Ernawati, J., \& Santosa, H. (2019). Visual Elements Influence at the Facade of Historical Buildings in Jalan Panglima Sudirman Corridor Batu, Indonesia. Local Wisdom: Jurnal Ilmiah Kajian Kearifan Lokal, 11(2), 138-145. https://doi.org/10.26905/lw.v11i2.3004 